\title{
Povezanost između obilježja partnerskih sukoba s doživljajem emocionalnog sagorijevanja i procjenom budućnosti partnerske veze
}

\author{
Slavica Blažeka Kokorić* \\ sblazeka@pravo.hr \\ https://orcid.org/0000-0002-3846-8384 \\ Gordana Stolfa $*$ \\ gordana.stolfa@mail.inet.hr \\ https://orcid.org/0000-0001-5324-8139
}

\author{
https://doi.org/10.31192/np.19.2.13 \\ UDK: 392.6:316.482 \\ 613.86 \\ Prethodno priopćenje / Preliminary communication \\ Primljeno: 25. studenog 2020. \\ Prihvaćeno: 24. lipnja 2021.
}

U radu su prikazani rezultati istraživanja čiji je cilj utvrditi postoji li povezanost između obilježja partnerskih sukoba s doživljajem emocionalnog sagorijevanja $i$ procjenom budućnosti partnerske veze. Podaci su prikupljeni anketnim upitnikom na uzorku od 149 osoba koje su radi teškoća u partnerskom odnosu uključene u psihosocijalno savjetovanje. U analizi podataka korištena je deskriptivna statistika, hi-kvadrat test, $t$-test te Pearsonov koeficijent korelacije. Rezultati su pokazali da veći stupanj izraženosti neslaganja u partnerskom odnosu korelira s manjom spremnošću na aktivno ulaganje u odnos, s češćim emocionalnim sagorijevanjem $i$ odustajanjem od odnosa. Utvrdeno je da učestalije efikasno rješavanje sukoba i sposobnost razrješavanja sukoba korelira s većom spremnošću na aktivno ulaganje u odnos te s manjim emocionalnim sagorijevanjem $i$ odustajanjem od odnosa. Češća iskustva s negativnim ishodima sukobljavanja u obliku produbljivanja sukoba povezana su s češćim doživljajem emocionalnog sagorijevanja i odustajanjem od partnerskog odnosa. Zaključno se ističe važnost dostupnosti različitih usluga profesionalne podrške usmjerene na pravovremeno, konstruktivno razrješavanje partnerskih sukoba, prevenciju emocionalnog sagorijevanja i nestabilnost partnerskog odnosa.

Ključne riječi: efikasnost rješavanja sukoba, emocionalno sagorijevanje, partnerski sukobi, odustajanje od odnosa.

\footnotetext{
* Prof. dr. sc. Slavica Blažeka Kokorić, Sveučilište u Zagrebu, Pravni fakultet, Studijski centar socijalnog rada, Nazorova 51, HR-10000 Zagreb.

** Gordana Stolfa, magistra obiteljske medijacije, Dom za starije osobe »Mali Kartec«, Lina Bolmarčića 1, HR-51500 Krk.
} 


\section{Uvod}

Sukobi su sastavni dio partnerskih odnosa, a rezultat su nekompatibilnih potreba, interesa, želja i ciljeva, ${ }^{1}$ te kao odraz razlika u vrijednostima partnera. Sukobi nastaju u situacijama u kojima postoje suprotna zbivanja i tendencije, ponašanja, čuvstva. ${ }^{2} \mathrm{U}$ njima se ogledaju nezadovoljene potrebe, rivalstva, nesigurnosti, razlike u percepciji problema, otpori prema promjenama, teškoće u komunikaciji u partnerskom odnosu itd. ${ }^{3}$ Partnerski odnosi se međusobno razlikuju po učestalosti otvorenih i prikrivenih sukoba, po sadržaju, prirodi i opsegu njihova iskazivanja i sposobnosti njihova razrješavanja. Istraživanja pokazuju da se redoviti manji sukobi obično pojavljuju u partnerskim odnosima na tjednoj ili mjesečnoj razini, a veće svađe jednom ili nekoliko puta godišnje, ${ }^{4}$ pri čemu se učestalost sukoba u partnerskom odnosu uobičajeno povećava $\mathrm{s}$ protekom vremena, uz istovremeno sve rjeđe zadržavanje smirenosti u reakcijama partnera na sukob. ${ }^{5}$ Nemogućnost konstruktivnog upravljanja sukobima izaziva nezadovoljstvo u partnerskoj vezi, a česti, snažni i dugotrajni sukobi ostavljaju višestruke negativne posljedice na tjelesno i psihičko zdravlje supružnika te snažno utječu na nestabilnost braka. ${ }^{6}$

U razumijevanju dinamike bračnih sukoba važno je utvrditi kakva su uvjerenja partnera o efikasnosti rješavanja sukoba i mogućim ishodima sukoba te kakva je njihova percepcija o tome je li vrijedno dalje ulagati napore u rješavanje problema i održavanje bračnog odnosa ili je bolje odustati od odnosa. Doživljaj efikasnosti rješavanja partnerskih sukoba stvara iskustvo partnera o ishodima prethodnih konfliktnih situacija, odnosno njihova procjena koliko često su one završavale razrješavanjem, potiskivanjem ili produbljivanjem sukoba. ${ }^{7}$

U dinamici narušenog bračnog odnosa očekivano je da postoji veća učestalost snažnih, dugotrajnih sukoba koji opetovano eruptiraju te ostavljaju višestru-

${ }^{1}$ Usp. Vera ĆUBELA ADORIĆ, Rafaela KOVAČ, Skala uspješnosti rješavanja bračnih konflikata, u: Ivana TUCAK JUNAKOVIĆ i dr. (ur.), Zbirka psihologijskih skala $i$ upitnika, sv. 5, Zadar, Sveučilište u Zadru, 2010, 85-92, 85.

2 Usp. Nina PEĆNIK, Sukobi i strategije njihova rješavanja, Ljetopis socijalnog rada, 1 (1994) 1, $59-65,59$.

${ }^{3}$ Usp. Gordana STOLFA, Obilježja partnerskih sukoba i odrednice njihova rješavanja, završni specijalistički rad, Zagreb, Studijski centar socijalnog rada, Pravni fakultet Sveučilišta u Zagrebu, 2016, 1.

${ }^{4}$ Usp. Slavica BLAŽEKA KOKORIĆ, Povezanost iskustava u primarnoj obitelji s obilježjima partnerskih odnosa, doktorska disertacija, Zagreb, Studijski centar socijalnog rada, Pravni fakultet, Sveučilište u Zagrebu, 2005, 121-122.

${ }^{5}$ Usp. Laura STAFFORD, Suzan L. KLINE, Caroline T. RANKIN, Married individuals, cohabiters, and cohabiters who marry. A longitudinal study of relational and individual well-being, Journal of Social and Personal Relationships, 21 (2004) 2, 231-248, 231.

${ }^{6}$ Usp. Mira ČUDINA-OBRADOVIĆ, Josip OBRADOVIĆ, Psihologija braka i obitelji, Zagreb, Golden marketing - Tehnička knjiga, 2006, 108.

${ }^{7}$ Usp. Draženka SKUPNJAK, Rješavanje konflikata i vještine asertivnosti, Varaždinski učitelj. Digitalni stručni časopis za odgoj i obrazovanje, 3 (2020) 3, 98-116, 105. 
ke nepoželjne posljedice, narušavajući intimne odnose, bračno zadovoljstvo i kvalitetu braka. ${ }^{8} \mathrm{U}$ uvjetima dugotrajnog sukoba i nerazriješenih emocionalnih tenzija, s vremenom dolazi do postupnog slabljenja i potpunog nestajanja osjećaja međusobne naklonosti i bliskosti među partnerima, a nerijetko i do pojave emocionalnog sagorijevanja. ${ }^{9}$ Emocionalno sagorijevanje se može odrediti kao stanje bolnog fizičkog, emocionalnog i psihološkog umora, fizičke, mentalne i emocionalne iscrpljenosti koje se događa u partnerskim vezama kada ne postoji kompatibilnost između očekivanja partnera i njihova doživljaja stvarnosti. ${ }^{10} \mathrm{U}$ bračnom odnosu manifestira se u doživljaju emocionalne iscrpljenosti i otupjelosti žene ili muža, dok na koncu oba supružnika ne osjete sličan stupanj emocionalne hladnoće. ${ }^{11}$ Bračno sagorijevanje se postupno pojačava sve većim udaljavanjem te $\mathrm{u}$ konačnici može završiti rastavom braka. ${ }^{12} \mathrm{U}$ zadnjoj fazi partneri izražavaju naglašen negativan stav prema budućnosti svojega odnosa koji u njima izaziva uvjerenje da više nema smisla ulagati napore u održavanje partnerskog odnosa jer on za njih više nije značajan. ${ }^{13}$ Koncept emocionalnog sagorijevanja danas se često koristi u terapiji parova s narušenim partnerskim odnosima. On podrazumijeva korištenje integrativnog pristupa koji kombinira prednosti psihodinamskog, sistemskog i bihevioralnog pristupa. Umjesto fokusa na dijagnosticiranju individualne psihopatologije ili psihopatologije para, ovaj pristup težište stavlja na razumijevanje fenomena emocionalnog sagorijevanja koji nastaje u partnerskom odnosu kao posljedica postupnog smanjivanja doživljaja osobne snage i djelotvornosti zbog kumulativnog djelovanja kontinuiranog stresa i pritiska izvan ili unutar partnerskog odnosa. ${ }^{14}$

Različita istraživanja potvrdila su povezanost između stupnja emocionalnog sagorijevanja i odustajanja od ulaganja u odnos, pa je tako primjerice $u$ jednom istraživanju utvrđeno da žene koje žele nastaviti bračni život iskazuju značajno manju razinu bračnog sagorijevanja u odnosu na žene koje su podnijele zahtjev za rastava braka. ${ }^{15}$ Također, različita su istraživanja pokušala

${ }^{8}$ Usp. Čudina-Obradović, Obradović, Psihologija braka i obitelji..., 108.

${ }^{9}$ Usp. Amin ASGARI, Kourosh GOODARZI, The Effectiveness of Emotional Schema Therapy on Marital Burnout on the Brink of Divorce, Middle Eastern Journal of Disability Studies, 8 (2018) 55-64, 55.

${ }^{10}$ Usp. Anahita Khodabakhshi KOOLAEE, Nastaran ADIBRAD, Bahram Saleh SEDGH, The comparison of relationship beliefs and couple's burnout in women who apply for divorce and women who want to continue their marital life, Iranian journal of psychiatry, 5 (2010) 1, 35-39, 35.

${ }^{11}$ Usp. Rula Odeh ALSAWALQA, Marriage Burnout. When the Emotions Exhausted Quietly Quantitative Research, Iranian Journal of Psychiatry and Behavioral Sciences, 13 (2019) 2, e68833; doi: 10.5812/ijpbs.68833.

${ }^{12}$ Usp. John Mordecai GOTTMAN, A theory of marital dissolution and stability, Journal of family psychology, 7 (1993) 1, 57-75, 75.

${ }^{13}$ Usp. Alsawalqa, Marriage Burnout...

${ }^{14}$ Usp. Ayala Malach PINES, Couple burnout. Causes and cures, New York, London, Routledge, 2013, 1-78.

${ }^{15}$ Usp. Koolaee, Adibrad, Sedgh, The comparison of relationship..., 35. 
definirati prediktore bračnog sagorijevanja. U istraživanju na uzorku od 159 udanih žena, rezultati regresijske analize pokazali su da osobine ličnosti (neuroticizam, ekstroverzija i savjesnost) te seksualna intimnost određuju čak 41,6 \% bračnog sagorijevanja. ${ }^{16}$ Također, $\mathrm{u}$ istraživanju na uzorku od 435 oženjenih muškaraca i udanih žena, rezultati linearne multiple regresijske analize utvrđuju da je najbolji prediktor sagorijevanja u braku stupanj bračne prilagodbe kojim je objašnjeno čak $40,7 \%$ varijance. ${ }^{17}$

Prepoznavanje čimbenika koji uzrokuju emocionalno sagorijevanje u braku izrazito je važno u kontekstu prevencije bračne nestabilnosti i unapređivanja kvalitete braka. Nadalje, u kontekstu održavanja motivacije i nastojanja partnera da pronađu adekvatne načine upravljanja međusobnim sukobima naglašava se važnost doživljaja predanosti vezi. ${ }^{18}$ Također, ističe se da se nezadovoljstvo odnosom, pa i rastava braka, mogu predvidjeti upravo na temelju nekih značajki lošeg upravljanja konfliktima, te da se znakovi opasnosti - poput tendencije povlačenja, negativnog interpretiranja i invalidiranja, te eskaliranja konflikta - mogu opaziti i godinama prije pojave negativnih ishoda. S obzirom na neupitnu važnost prepoznavanja »znakova opasnosti« koji izazivaju nestabilnost partnerskog odnosa, u ovom radu je obrađena povezanost između obilježja partnerskih sukoba, doživljaja emocionalnog sagorijevanja te percepcije budućnosti partnerske veze kod osoba koje su radi teškoća u partnerskom odnosu uključene u savjetovanje. Imajući u vidu nalaze prijašnjih istraživanja koji utvrđuju razlike u reakcijama muškaraca i žena na kvalitetu braka, pri čemu su žene u odnosu na muškarce osjetljivije na emocionalne promjene u partnerskim odnosima, snažnije doživljavaju neugodu u situacijama sukoba te obično prve nastoje popraviti odnose ${ }^{19}$ ovim istraživanjem želi se dodatno provjeriti imaju li spolne razlike takav učinak i kod muškaraca i žena koji su zbog teškoća u partnerskom odnosu zatražili stručnu pomoć.

\section{Metodologija istraživanja}

\subsection{Cilj istraživanja}

Cilj istraživanja je utvrditi subjektivnu procjenu doživljaja partnerskih sukoba, emocionalnog sagorijevanja i budućnosti partnerske veze kod osoba

\footnotetext{
${ }^{16}$ Usp. Ali Mohammad NAZARI, Prediction of marital burnout based on personality traits and sexual intimacy in married woman nurses in selected private hospitals in Tehran, Preventive Care in. Nursing and Midwifery Journal, 6 (2016) 3, 59-70, 59.

${ }^{17}$ Usp. Burhan ÇAPRİ, Zafer GÖKÇAKAN, The variables predicting couple burnout, Elementary Education Online, 12 (2013) 2, 561-574, 561.

${ }^{18}$ Usp. Ćubela Adorić, Kovač, Skala uspješnosti..., 85.

${ }^{19}$ Usp. Čudina-Obradović, Obradović, Psihologija braka i obitelji..., 143.
} 
koje su radi teškoća u partnerskom odnosu uključene u savjetovanje, postoje li razlike $u$ navedenim procjenama prema spolu te postoji li povezanost između obilježja partnerskih sukoba s doživljajem emocionalnog sagorijevanja i budućnosti veze.

\subsection{Hipoteze istraživanja}

Hipoteza 1. Očekuje se da u partnerskim odnosima sudionika istraživanja prevladavaju veći sukobi te da većina sukoba završava produbljivanjem, a ne razrješavanjem konflikata.

Hipoteza 2. Očekuje se da sudionici istraživanja učestalo doživljavaju problem emocionalnog sagorijevanja te da većina njih budućnost partnerskog odnosa doživljava na negativan način.

Hipoteza 3. Očekuje se da će žene za razliku od muškaraca partnerske sukobe doživljavati češćim i dubljim, a njihovo rješavanje slabije efikasnim, uz izraženiji doživljaj emocionalnog sagorijevanja. Istovremeno očekuje se da će žene u odnosu na muškarce biti spremnije zalagati se za budućnost partnerskog odnosa.

Hipoteza 4. Očekuje se da će emocionalno sagorijevanje i odustajanje od odnosa češće iskazivati sudionici u čijim je partnerskim odnosima izraženije neslaganje i manja efikasnost rješavanja partnerskih sukoba.

\subsection{Sudionici istraživanja}

U istraživanju je sudjelovalo ukupno 149 osoba koje su zbog teškoća u partnerskom odnosu bile uključene u proces individualnog ili partnerskog savjetovanja u okviru jednog obiteljskog centra na području Republike Hrvatske. ${ }^{20}$ U uzorku je bila 91 žena (61,07 \%) i 58 muškaraca (38,93\%). Sudionici su u dobi od minimalno 22 do maksimalno 66 godina starosti $(\mathrm{M}=38,56 ; \mathrm{SD}=8,26)$. Većina sudionika 46,53 \% je u braku, 31,25 \% u postupku razvoda, 11,8 \% u izvanbračnoj vezi, a 10,42 \% je razvedeno. Kod 20,41\% sudionika partnerska veza traje manje od 5 godina, kod 35,37 \% od 5 do 10 godina, kod 27,89 \% 10-20 godina, a kod $16,33 \%$ više od 20 godina.

\footnotetext{
${ }^{20} \mathrm{U}$ pojedinim varijablama uzorak je značajno manji jer neki ispitanici nisu u cijelosti popunili upitnik. S obzirom na specifičan kontekst u kojem je provođeno ovo istraživanje, ne iznenađuje da je dio sudionika istraživanja, zbog emocionalne preokupiranosti problemima u partnerskom odnosu, bio manje spreman pažljivo popuniti cijeli upitnik, što je smanjilo veličinu uzorka na pojedinim varijablama.
} 


\subsection{Instrumenti istraživanja}

a) Upitnik o socio-demografskim obilježjima sudionika istraživanja - Upitnik sadrži 11 pitanja koji se odnose na spol i dob ispitanika, razinu obrazovanja, radni i bračni status, dužinu partnerske veze i dob ulaska u vezu, uključenost u proces savjetovanja, broj i starost djece te socioekonomske prilike u obitelji.

b) Upitnik bračnog sagorijevanja ${ }^{21}$ - Upitnik je namijenjen ispitivanju doživljaja emocionalnog sagorijevanja u bračnom odnosu/partnerskoj vezi. Sadrži 12 čestica. Od sudionika se traži da za svaku česticu, na skali od 0 (nikad) do 6 (svaki dan), procijene učestalost pojavljivanja nekog osjećaja ili ponašanja iz partnerskog odnosa. Primjeri čestica iz ovog upitnika su: »Moja veza me emocionalno iscrpljuje«, »Osjećam se frustrirano u vezi.« Ukupan rezultat dobiva se izračunavanjem prosječnog rezultata svih čestica, pri čemu prethodno treba rekodirati vrijednosti čestica broj 3 (»Uspješno rješavam probleme u mojoj vezi«) i broj 10 (»Moja veza me čini snažnijim/snažnijom«). Ukupni rezultat se kreće u teorijskom rasponu od 0 do 72 . Upitnik je u hrvatskoj verziji prvi put primijenjen u ovom istraživanju, uz dobivenu suglasnost autorice upitnika. $\mathrm{Na}$ uzorku ovog istraživanja potvrđena je visoka pouzdanost upitnika (Cronbach $\alpha=0,88)$. Provedena faktorska analiza upitnika metodom zajedničkih faktora na uzorku od 86 ispitanika koji su u cijelosti ispunili upitnik, pokazala je opravdanost jednofaktorske strukture, pri čemu dobiveni faktor objašnjava 41,09 \% zajedničke varijance čestica na upitniku. ${ }^{22}$

c) Upitnik o budućnosti partnerske veze - upitnik ima šest čestica koje su preuzete iz Skale bračne prilagodbe. ${ }^{23}$ Upitnikom se ispituje doživljaj budućnosti partnerskog odnosa. Od sudionika istraživanja se tražilo da izraze stupanj svog slaganja sa svakom od šest tvrdnji, na skali od 1 (uopće se ne slažem) do 5 (u potpunosti se slažem). Faktorska analiza provedena metodom zajedničkih faktora na uzorku od 142 sudionika ovog istraživanja pokazala je dvofaktorsku strukturu upitnika koji objašnjava $71 \%$ zajedničke varijance svih čestica u upitniku. Nakon dodatno provedene faktorske analize uz korištenje kosokutne oblimin rotacije, rezultati su grupirani u dvije supskale: odustajanje od odnosa i spremnost na aktivno ulaganje u odnos. Rezultati na supskali odustajanje od

\footnotetext{
${ }^{21}$ Usp. Rebecca J. ERICKSON, Marital Burnout (MB), u: Barry F. PERLMUTTER i dr. (ur.), Handbook of family measurement techniques - Instruments E Index, sv. 3, Thousand Oaks, London, New Delhi, Sage Publications, 2001, 159.

${ }^{22}$ Budući da je faktorska analiza provedena na relativno malom uzorku u odnosu na broj varijabli u upitniku, u budućim istraživanjima na širem uzorku poželjno je dodatno provjeriti faktorsku strukturu ovog upitnika.

${ }^{23}$ Usp. Graham B. SPANIER, Measuring dyadic adjustment: New scales for assessing the quality of marriage and similar dyads, Journal of Marriage and the Family, 38 (1976) 15-28, 28. Upitnik je ranije korišten u hrvatskoj verziji (usp. Tihana VRHOVSKI, Kvaliteta braka i neke sociodemografske varijable, diplomski rad, Zagreb, Filozofski fakultet u Zagrebu, 2004, 27-31).
} 
odnosa dobivaju se zbrajanjem čestica 1, 2, 3 i rekodirane čestice 4 (primjer čestice za ovu supskalu: »Odnos s mojim partnerom/icom nema šanse za uspjeh i nema više ničeg što bih mogao/mogla učiniti da održim tu vezu«). Rezultati na supskali spremnost na aktivno ulaganje u odnos dobivaju se zbrajanjem čestice 5 i 6 (primjer čestice za ovu supskalu: »Jako želim da moja veza uspije i učinio/ la bih sve da se to dogodi«). Pouzdanost upitnika za supskalu odustajanje od odnosa iznosi Cronbach $\alpha=0,60$, a za supskalu spremnost na aktivno ulaganje $\mathrm{u}$ odnos Cronbach $\alpha=0,93$.

d) Upitnik sukoba i načina rješavanja problema u partnerskom odnosu ${ }^{24}$ upitnik mjeri učestalost većih i manjih konflikata, područje i stupanj izraženosti konflikata, uspješnost rješavanja konflikata u pojedinom području, strategije rješavanja konflikata te ishod konflikata. Za potrebe ovog istraživanja korišteni su u hrvatskoj verziji ${ }^{25}$ sljedeći dijelovi upitnika:

1. Frekvencija konflikta - Ispituje se učestalost pojavljivanja manjih neslaganja i većih sukoba u partnerkom odnosu zaokruživanjem jednog od odgovora: jednom godišnje ili rjeđe, svakih 4-6 mjeseci, svaka 2-3 mjeseca, jednom ili dva puta mjesečno, jednom ili dva puta tjedno te skoro svaki dan.

2. Stupanj izraženosti neslaganja - Ispituje se stupanj izraženosti neslaganja kroz 20 područja mogućih sukoba (čestice su predstavljene u tablici 1) na ljestvici od 0 (nikad) do 10 (uvijek).

3. Efikasnost rješavanja sukoba - Ispituje se uspješnost rješavanja partnerskih sukoba kroz 20 područja mogućih sukoba (čestice su predstavljene u tablici 1) na ljestvici od 0 (nikad) do 10 (uvijek).

4. Ishod rješavanja konflikta - Od sudionika se traži da uz navedenih 13 tvrdnji označe koliko se neka tvrdnja odnosi na njihovo iskustvo ishoda rješavanja sukoba u partnerskom odnosu. Raspon mogućih odgovora je od 0 (nikad) do 3 (redovito). Provedena faktorska analiza metodom zajedničkih faktora na uzorku od 140 sudionika ovog istraživanja, potvrdila je dvofaktorsku strukturu upitnika kojom je objašnjeno 52 \% zajedničke varijance svih čestica u upitniku. Rezultati provedene faktorske analize uz dva zadana faktora te korištenja kosokutne oblimin rotacije, pokazali su grupiranje čestica u dvije supskale: razrješavanje i produbljivanje parterskih sukoba. Supskala razrješavanje partnerskih sukoba sadrži čestice 1, 2, 3, 4, 5 (primjeri čestica: »Osjećamo da smo riješili nesporazum u cjelini«, »Osjećamo se bliži jedno drugom negoli prije svađe«). Faktor pro-

\footnotetext{
${ }^{24}$ Usp. Patricia K. KERIG, Conflicts and Problem-solving Scales (CPS), u: Barry F. PERLMUTTER i dr. (ur.), Handbook offamily measurement techniques - Instruments \& Index, sv. 3, Thousand Oaks, London, New Delhi, Sage Publications, 2001, 131-135.

${ }^{25}$ Upitnik je već korišten u hrvatskoj verziji (usp. Blažeka Kokorić, Povezanost iskustava..., 9294).
} 
dubljivanje partnerskog sukoba sadrži čestice od 6, 7, 8, 9, 10, 11 (primjeri čestica: »Nakon svađe osjećamo još veću ljutnju jedno prema drugome«, »Osjećamo da je pričanje o problemu bio veliki gubitak vremena«). Zasićenje čestica 12. i 13. je pokazalo da ih nije opravdano koristiti ih u izračunu ukupnog rezultata, pa su navedene čestice izbačene iz daljnje obrade. Obje supskale imaju dobru pouzdanost (za supskalu razrješavanje partnerskog sukoba Cronbach $\alpha=0,85$, a za supskalu produbljivanje partnerskog sukoba Cronbach $\alpha=0,78)$.

\subsection{Postupak $i$ etički aspekti istraživanja}

Istraživanje je provedeno anketiranjem korisnika usluge psihosocijalnog savjetovanja u jednom obiteljskom centru u Hrvatskoj. Prije provođenja istraživanja dobivena je suglasnost Etičkog povjerenstva Pravnog fakulteta u Zagrebu, dozvola za provedbu istraživanja od strane ravnatelja centra za socijalnu skrb u čijoj se podružnici obiteljskog centra provodilo istraživanje te pristanak sudionika za sudjelovanje u istraživanju. Prije provođenja istraživanja sudionike se upoznalo $s$ temom i svrhom istraživanja te im je objašnjeno da je sudjelovanje $\mathrm{u}$ istraživanju dobrovoljno i anonimno. Tijekom provođenja istraživanja bila je osigurana privatnost i anonimnost. Ispunjavanje anketnog upitnika je trajalo oko 30 minuta. Na završetku istraživanja sudionicima je upućena zahvalna za sudjelovanje u istraživanju.

\subsection{Metode obrade podataka}

Prikupljeni podaci analizirani su pomoću programskog statističkog paketa SPSS 23. U obradi podataka je korištena deskriptivna statistika, hi-kvadrat test, t-test te Pearsonov koeficijent korelacije.

\section{Rezultati}

Istraživanjem se najprije ispitalo kakav je stupanj izraženosti neslaganja partnera u različitim područjima sukobljavanja te u koliko su sudionici istraživanja zadovoljni razinom efikasnosti rješavanja pojedinih područja sukoba (tablica 1). Na Likertovoj skali odgovora od 0 (nikad) do 10 (uvijek), prosječne vrijednosti izraženosti neslaganja u različitim područjima sukoba kreću se od minimalno $M=2,02$ do maksimalno $M=6,79$. Sudionici istraživanja su iskazali da najizraženije neslaganje doživljavaju zbog razlika u osobnosti, problema u međusobnoj komunikaciji, nezadovoljstva ponašanjem partnera, zbog načina donošenja odluka i seksualnih odnosa, zbog različitih ciljeva i vrijednosti, nov- 
ca i brige oko financija, ljubomore, nepovjerenja i nevjere te problema s iskazivanjem privrženosti i bliskosti. $S$ druge strane, najrjeđe su prisutni sukobi zbog ovisnosti, religije i odnosa s prijateljima. Kod procjene zadovoljstva razinom efikasnosti rješavanja područja sukoba, dobivene prosječne vrijednosti kreću se od minimalno $M=4,27$ do maksimalno $M=6,57$. Sudionici istraživanja najveću efikasnost rješavanja sukoba doživljavaju u području koje se tiče odnosa s prijateljima, religije te odgoja djece, dok najmanju efikasnost vide u rješavanja sukoba koji se tiču međusobne komunikacije, ljubomore, nepovjerenja i izvanbračnih afera, razlika u osobnosti, nezadovoljstva seksualnim odnosima i ponašanjem partnera.

Tablica 1. Stupanj izraženosti neslaganja i efikasnosti rješavanja sukoba po područjima sukoba

\begin{tabular}{|c|c|c|c|c|}
\hline \multicolumn{2}{|c|}{$\begin{array}{c}\begin{array}{c}\text { Stupanj izraženosti } \\
\text { neslaganja }\end{array} \\
(\min .=0, \text { maks. }=10)\end{array}$} & \multirow[t]{2}{*}{ Područje sukoba } & \multicolumn{2}{|c|}{$\begin{array}{c}\text { Efikasnost } \\
\text { rješavanja sukoba } \\
(\text { min. }=0, \text { maks. }=10)\end{array}$} \\
\hline $\mathbf{M}$ & SD & & $\mathbf{M}$ & SD \\
\hline 4,87 & 3,29 & 1. Problemi koji se tiču odgoja djece & 6,00 & 3,27 \\
\hline 4,56 & 3,54 & 2. Odluke vezane za karijeru / posao & 5,53 & 3,61 \\
\hline 4,93 & 3,52 & 3. Usklađivanje privatnih i poslovnih obaveza & 5,74 & 3,37 \\
\hline 4,15 & 3,53 & 4. Kućanski poslovi & 5,67 & 3,45 \\
\hline 5,38 & 3,65 & 5. Novac, briga oko obiteljskih financija & 5,35 & 3,51 \\
\hline 4,33 & 3,38 & 6. Aktivnosti u slobodno vrijeme & 5,22 & 3,48 \\
\hline 4,89 & 3,54 & 7. Odnosi s rodbinom & 5,55 & 3,59 \\
\hline 3,77 & 3,42 & 8. Odnosi s prijateljima & 6,57 & 3,31 \\
\hline 5,35 & 4,25 & 9. Ljubomora, nepovjerenje, izvanbračne afere & 4,28 & 4,04 \\
\hline 5,47 & 3,81 & 10. Seksualni odnosi s partnerom & 4,53 & 3,70 \\
\hline 6,49 & 3,17 & 11. Međusobna komunikacija & 4,27 & 3,33 \\
\hline 5,27 & 3,57 & $\begin{array}{l}\text { 12. Iskazivanje privrženosti, intimnosti i } \\
\text { bliskosti }\end{array}$ & 4,66 & 3,53 \\
\hline 4,88 & 3,33 & 13. Količina vremena provedena zajedno & 5,22 & 3,30 \\
\hline 2,02 & 3,45 & 14. Ovisnost (o alkoholu, drogama, kockanju...) & 6,02 & 4,37 \\
\hline 5,95 & 3,34 & 15. Nezadovoljstvo ponašanjem partnera & 4,55 & 3,04 \\
\hline 5,46 & 3,51 & 16. Različiti ciljevi, vrijednosti, životna filozofija & 4,86 & 3,39 \\
\hline 2,55 & 3,69 & 17. Vjera / religija & 6,35 & 4,18 \\
\hline 5,48 & 2,98 & 18. Donošenje odluka & 5,64 & 3,01 \\
\hline 6,79 & 3,04 & 19. Razlike u osobnosti & 4,45 & 3,03 \\
\hline 4,63 & 3,66 & $\begin{array}{l}\text { 20. Razlike u očekivanju od muško-ženskih } \\
\text { uloga }\end{array}$ & 5,22 & 3,40 \\
\hline 4,86 & 1,97 & Ukupno & 5,33 & 2,17 \\
\hline
\end{tabular}

Najviše sudionika istraživanja, njih $29,73 \%$, izvijestilo je da manje sukobe u partnerskom odnosu doživljava gotovo svaki dan, 26,35 \% tjedno te $27,03 \%$ mjesečno. Distribucija odgovora o učestalosti većih sukoba je bitno drukčija pa 
tako veće partnerske sukobe gotovo svaki dan doživljava samo $6,8 \%$ sudionika, tjedno 21,77 \% sudionika, a mjesečno $20,41 \%$. Gotovo četvrtina sudionika (njih 23,13 \%) izvještava da veće sukobe doživljava samo jednom godišnje ili još rjeđe.

Usporedba prosječnih vrijednosti pokazuje da sudionici istraživanja u partnerskom odnosu znatno češće doživljavaju manje prepirke $(M=4,55 ; \mathrm{SD}=1,36$, Min=1, Max=6) nego velike svađe $(M=3,31 ; S D=1,61$, Min=1, $M a x=6)$.

Što se tiče procjene ishoda rješavanja konflikata (tablica 2), utvrđeno je da partnerski sukobi sudionika istraživanja češće završavaju produbljivanjem nego razrješavanjem sukoba.

Tablica 2. Deskriptivni podaci o ishodima rješavanja konflikata

\begin{tabular}{|l|c|c|c|c|c|}
\hline \multicolumn{1}{|c|}{ ISHODI KONFLIKATA } & N & Min. & Maks. & M & SD \\
\hline Razrješavanje sukoba & 145 & 0,00 & 3,00 & 1,37 & 0,71 \\
\hline Produbljivanje sukoba & 141 & 0,17 & 3,00 & 1,77 & 0,79 \\
\hline
\end{tabular}

Prikazani rezultati pokazuju da je prva hipoteza u kojoj se očekivalo da će u partnerskim odnosima sudionika istraživanja prevladavati veći sukobi te da će većina sukoba završavati produbljivanjem, a ne razrješavanjem konflikata, potvrđena samo u dijelu koji se tiče ishoda konflikata. Naime, potvrđeno je da su partnerski odnosi osoba koje su uključene u proces savjetovanja uvelike opterećeni neriješenim konfliktima, no partnerski sukobi se češće manifestiraju u obliku manjih prepirka i svađa, a ne velikih sukoba.

Tablica 3. Doživljaj emocionalnog sagorijevanja i budućnosti partnerske veze

\begin{tabular}{|l|c|c|c|c|c|}
\hline & N & Min. & Maks. & M & SD \\
\hline Emocionalno sagorijevanje & 86 & 1,25 & 5,67 & 3,89 & 1,15 \\
\hline Spremnost na aktivno ulaganje u odnos & 145 & 1,00 & 5,00 & 2,94 & 1,43 \\
\hline Odustajanje od odnosa & 145 & 1,00 & 5,00 & 2,96 & 0,97 \\
\hline
\end{tabular}

Kod procjene emocionalnog sagorijevanja, na skali mogućih odgovora od 0 = nikad do 6 = svaki dan, dobivena je prosječna vrijednost $M=3,89$ što pokazuje da sudionici istraživanja emocionalno sagorijevanje doživljavaju u prosjeku na tjednoj razini. U procjeni budućnosti veze, sudionici podjednako izražavaju spremnost na aktivno ulaganje u odnos kao i na odustajanje od odnosa. Dakle, druga hipoteza potvrđena je u dijelu u kojem se očekivalo da sudionici istraživanja učestalo doživljavaju problem emocionalnog sagorijevanja, dok istovremeno nije potvrđeno da većina sudionika budućnost partnerskog odnosa doživljava na negativan način.

U idućem koraku provjereno je postoje li razlike u procjenama partnerskih sukoba i doživljaju emocionalnog sagorijevanja i budućnosti partnerskog odnosa u odnosu na spol ispitanika. Rezultati hi-kvadrat testa pokazali su da nema značajnih razlika između muškaraca i žena u procjenama učestalosti pojav- 
ljivanja manjih sukoba $\left(\chi^{2}=2,51 ; d f=5 ; p>0,05\right)$, kao ni većih sukoba $\left(\chi^{2}=2,32\right.$; $d f=5 ; p>0,05)$. Dakle, ni hipoteza 3 nije potvrđena.

Razlike prema spolu utvrđene su u procjenama izraženosti neslaganja oko obiteljskih financija i problema ovisnosti. Rezultati t-testa pokazali su da muškarci u odnosu na žene neslaganje oko obiteljskih financija procjenjuju nižim vrijednostima ( $p<0,05, t=-2,05 ; d f=131)$, jednako kao i neslaganje oko problema ovisnosti $(p<0,05, t=-2,38 ; d f=124)$. S druge strane, kada je u pitanju efikasnost rješavanja navedenih sukoba, žene su tu značajno kritičnije od muškaraca te procjenjuju nižim vrijednostima efikasnost rješavanja neslaganja oko obiteljskih financija $(p<0,05, t=2,12 ; d f=134)$, kao i neslaganja oko problema ovisnosti $(p<0,05, t=2,19 ; d f=122)$.

U procjenama ishoda konflikta nisu potvrđene očekivane statističke značajne razlike prema spolu (razrješavanje sukoba: $t=0,60 ; d f=143 ; p>0,05$, produbljivanje konflikta: $t=-0,30 ; d f=139 ; p>0,05)$. Rezultati t-testa pokazali su da nema statistički značajnih razlika između muškaraca i žena ni u procjenama emocionalnog sagorijevanja $(t=-0,93 ; d f=84 ; p>0,05)$, kao ni kod procjena spremnosti na aktivno ulaganje u odnos $(t=0,931 ; d f=143 ; p>0,05)$ i odustajanja od odnosa $(t=-1,01 ; d f=143 ; p>0,05)$.

Prema tome, dobiveni rezultati koji se odnose na provjeru spolnih razlika u najvećem dijelu ne potvrđuju treću hipotezu prema kojoj se očekivalo da će žene u odnosu na muškarce izvještavati o češćim partnerskim sukobima, o nižoj razini efikasnosti njihova rješavanja, uz izraženiji doživljaj emocionalnog sagorijevanja te da će biti spremnije aktivno ulagati u budućnost partnerskog odnosa. Treća hipoteza je potvrđena samo u dijelu koji se tiče veće kritičnosti žena, $\mathrm{tj}$. nižih procjena efikasnosti rješavanja partnerskih sukoba i to samo $u$ područjima sukobljavanja koja se tiču obiteljskih financija i problema ovisnosti.

Tablica 4. Povezanost obilježja partnerskih sukoba s doživljajem emocionalnog sagorijevanja u vezi te s procjenom budućnosti veze

\begin{tabular}{|l|c|c|c|}
\hline \multirow{2}{*}{ Stupanj izraženosti neslaganja } & $\begin{array}{c}\text { Emocionalno } \\
\text { sagorijevanje }\end{array}$ & $\begin{array}{c}\text { Spremnost } \\
\text { na aktivno } \\
\text { ulaganje u } \\
\text { odnos }\end{array}$ & $\begin{array}{c}\text { Odustajanje od } \\
\text { odnosa }\end{array}$ \\
\cline { 2 - 4 } & $\mathrm{r} 0,29^{*}$ & $-0,33^{*}$ & $0,54^{* *}$ \\
\hline \multirow{2}{*}{ Efikasnost rješavanja sukoba } & $\mathrm{N} 68$ & 108 & 107 \\
\hline \multirow{2}{*}{ Razrješavanje sukoba } & $\mathrm{r}-0,32^{*}$ & $0,45^{* *}$ & $-0,48^{* *}$ \\
\hline \multirow{2}{*}{ Produbljivanje sukoba } & $\mathrm{N}-0,48^{* *}$ & 104 & 104 \\
\cline { 2 - 4 } & $\mathrm{N} 85$ & $0,41^{* * *}$ & $-0,41^{* *}$ \\
\cline { 2 - 4 } & $\mathrm{r} 0,47^{* *}$ & 141 & 141 \\
\hline
\end{tabular}

$* * p<0,01 * p<0,05$ 
Dakle, postoji statistički značajna, ali niska razina povezanosti između promatranih obilježja partnerskih sukoba s percepcijom emocionalnog sagorijevanja i budućnosti partnerskog odnosa, dok je između izraženosti neslaganja i odustajanja od odnosa utvrđena umjerena razina povezanosti (tablica 4). Utvrđeno je da veća izraženost neslaganja u partnerskom odnosu pozitivno korelira $\mathrm{s}$ češćim emocionalnim sagorijevanjem i izraženijim odustajanjem od odnosa, a negativno sa spremnošću na aktivno ulaganje u odnos. Jednako tako potvrđeno je da veća efikasnost rješavanja sukoba korelira s manjim emocionalnim sagorijevanjem i manjim odustajanjem od odnosa te većom spremnošću na aktivno ulaganje u odnos. Nadalje, potvrđeno je da osobe koje češće uspješno razrješuju partnerske sukobe izvještavaju o značajno nižoj razini emocionalnog sagorijevanja i odustajanja od odnosa te o značajno višoj spremnosti na ulaganje u odnos. S druge strane, osobe $\mathrm{s}$ češćim iskustvom produbljivanja sukoba, izvještavaju o značajno višim razinama emocionalnog sagorijevanja te o značajno manjoj spremnosti na daljnje aktivno ulaganje u odnos. Može se zaključiti da je četvrta hipoteza u kojoj se očekivalo da će emocionalno sagorijevanje i odustajanje od odnosa više iskazivati sudionici u čijim partnerskim odnosima je izraženije neslaganje i niža efikasnost rješavanja partnerskih sukoba, potvrđena kao točna.

\section{Rasprava}

Dobiveni rezultati u ovom istraživanju pokazuju da se partnerski sukobi kod osoba uključenih u proces savjetovanja učestalije manifestiraju u obliku manjih prepirka i svađa, a ne velikih sukoba. Ovakvi rezultati pokazuju da, iako je hrvatsko društvo još uvijek prilično zatvoreno u pogledu traženja stručne podrške u rješavanju bračnih problema, nije opravdano očekivati da će se u proces savjetovanja radi teškoća u partnerskom odnosu uključiti samo osobe koje učestalo doživljavaju velike, već i manje partnerske sukobe. S druge strane, dobiveni nalazi potvrđuju da se teškoće u partnerskom odnosu ne moraju nužno manifestirati kroz velike, otvorene sukobe, već da one mogu biti i odraz učestalih manjih sukoba, ali i potisnutih konflikata. Navedeno se ne smije zanemariti pri procjeni stručnjaka o intenzitetu prisutnih teškoća u nekom partnerskom odnosu.

Nadalje, kada je riječ o učestalosti pojavljivanja partnerskih sukoba, dobivene rezultate u ovom istraživanju korisno je usporediti s nalazima istraživanja provedenog na uzorku 564 studenata, gdje je $61,7 \%$ studenata izjavilo da veće sukobe u partnerskom odnosu doživljava jednom godišnje ili rjeđe, a svega 6,2 $\%$ na tjednoj ili mjesečnoj razini. ${ }^{26}$ Iako u našem istraživanju nije potvrđeno

${ }^{26}$ Usp. Blažeka Kokorić, Povezanost iskustava..., 143-144. 
da u partnerskim odnosima sudionika istraživanja prevladavaju veći sukobi, vidljivo je da je u uzroku osoba uključenih u savjetovanje u odnosu na uzorak studenata, značajno više onih koji ozbiljne partnerske sukobe doživljavaju tjedno ili mjesečno (42,18 \%), a manje je onih koji veće sukobe doživljavaju jednom godišnje (23,13\%).

U ovom istraživanju dobiveni su i zanimljivi nalazi vezani uz dominantna područja sukobljavanja koje je zanimljivo usporediti s inozemnim istraživanjem provedenim u 100 kućanstava, metodom vođenja dnevnika od strane supružnika o svakodnevnim sukobima. ${ }^{27} \mathrm{Za}$ razliku od našeg istraživanja, navedeno istraživanje je pokazalo da kod parova koji su u stabilnom braku i imaju maloljetnu djecu, prevladavaju sukobi koji se tiču odgoja djece, podjele kućanskih poslova i odgovornosti, partnerske komunikacije te razlika u očekivanjima od slobodnog vremena i financija. Dakle, vidljivo je da se procjene područja sukobljavanja kod ovakvih parova značajno razlikuju od procjena osoba koje su zbog problema u partnerskom odnosu uključene u savjetovanje gdje dominiraju neslaganja koja se tiču osobnosti partnera, međusobne komunikacije, narušenog povjerenja ili iskustva nevjere.

Nadalje, rezultati ovog istraživanja pokazali su da je kod osoba koje su uključene u proces savjetovanja radi teškoća u partnerskom odnosu, emocionalno sagorijevanje vrlo često postoji te da je to važan fenomen o kojem trebaju voditi računa stručnjaci koji rade s navedenom populacijom. Naime, usporedba prosječnih vrijednosti na Upitniku o bračnom sagorijevanju (u kojem se teorijski raspon rezultata kreće od 0 do 72$)$ na uzorku ovog istraživanja $(M=37,45 ; \mathrm{SD}=$ $14,77) \mathrm{u}$ odnosu na vrijednosti koje su primjenom istog upitnika dobivene na uzorku od 205 zaposlenih udanih žena $(M=14,34$; $S D=12,67),{ }^{28}$ pokazuje da je emocionalno sagorijevanje tri puta više zastupljeno u našem uzorku osoba koje imaju teškoće u partnerskom odnosu.

Ovdje je važno istaknuti da, unatoč tome što sudionici ovog istraživanja u prosjeku emocionalno sagorijevanje doživljavaju na tjednoj razini, značajan dio njih zadržava pozitivan stav i uvjerenje da ima smisla ulagati u budućnosti partnerskog odnosa. S druge strane, rezultati korelacijske analize potvrdili su da se s većom izraženošću emocionalnog sagorijevanja, povećava spremnost na odustajanje od partnerskog odnosa, što ukazuje da pojačavanje doživljaja emocionalnog sagorijevanja treba shvatiti kao važan »znak opasnosti« koji izaziva porast nestabilnosti partnerskog odnosa. Naime, ako se ne zaustavi spirala daljnjeg razvoja emocionalnog sagorijevanja, poznato je da u konačnici to može dovesti do prekida partnerske veze. ${ }^{29}$ Stoga je važno u savjetovališnom radu

\footnotetext{
${ }^{27}$ Usp. Lauren M. PAPP, Mark E. CUMMINGS, Marcie C. GOEKE-MOREY, For Richer, for Poorer. Money as a Topic of Marital Conflict in the Home, Family relations, 58 (2009) 1, 91103; https://doi.org/10.1111/j.1741-3729.2008.00537.x.

${ }^{28}$ Usp. Rebecca J. ERICKSON, Reconceptualizing family work. The effect of emotion work on perceptions of marital quality, Journal of Marriage and the Family, 55 (1993) 4, 888-900, 893.

${ }^{29}$ Usp. Alsawalqa, Marriage Burnout...
} 
prepoznati ovaj »znak opasnosti« te mu posvetiti značajnu pažnju. Pri tome je posebno važno raditi na unapređivanju vještina iskazivanja međusobne podrške partnera jer postojeća istraživanja pokazuju da veća razina emocionalne podrške korelira s doživljajem manjeg emocionalnog sagorijevanja. ${ }^{30}$

Iako ranija istraživanja na drugačijim uzorcima upućuju na razlike između muškaraca i žena u pogledu doživljaja bračnog odnosa, ${ }^{31}$ zadovoljstva u vezi i načina reagiranja u partnerskim sukobima, ${ }^{32}$ treba reći da u ovom istraživanju na uzorku muškaraca i žena uključenih u proces savjetovanja nisu utvrđene očekivane spolne razlike u percepciji učestalosti konflikata, doživljaju emocionalnog sagorijevanja i budućnosti partnerskog odnosa. S druge strane, utvrđeno je da su žene značajno kritičnije od muževa u procjenama efikasnosti rješavanja sukoba. Usporedba prijašnjih nalaza s nalazima ovog istraživanja pokazuje da spolne razlike u procjeni različitih aspekata partnerskih odnosa mogu biti različite u specifičnim kontekstima, ali i fazama partnerskog odnosa. Također, vidljivo je da, ovisno o obilježjima uzorka, postoje neke nekonzistentnosti u rezultatima dosadašnjih istraživanja u pogledu efekta spola, što upućuje na potrebu za provođenjem daljnjih istraživanja u ovom području.

Poznato je da intenzivni i neriješeni partnerski sukobi ostavljaju višestruke negativne posljedice na fizičko i mentalno zdravlje partnera, ali i na ukupnu dinamiku obiteljskih i partnerskih odnosa. ${ }^{33}$ Rezultati ovog istraživanja pokazali su da se osobe uključene u savjetovanje radi teškoća u partnerskom odnosu nalaze na svojevrsnoj prekretnici u pogledu doživljaja budućnosti veze te da izražavaju različitu razinu motivacije za daljnje ulaganje u partnerski odnos, pri čemu u prosjeku podjednako izražavaju spremnost za aktivno ulaganje $u$ budućnost partnerskog odnosa kao i odustajanje od odnosa. Nadalje, utvrđeno je da je odustajanje od ulaganja u partnerski odnos značajno povezano s izraženošću partnerskog sukobljavanja i s procjenom efikasnosti razrješavanja sukoba. Također, potvrdilo se da su neriješeni konflikti povezani s višom razinom emocionalnog sagorijevanja. Navedeno je u skladu s ranijim nalazima u kojima je utvrđeno da napetosti koje proizlaze iz dugotrajnih sukoba među parovima uzrokuju izgaranje u braku i poremećaje u obiteljskom funkcioniranju, ${ }^{34}$ dok je s druge strane niža razina konflikata povezana s uvjerenjem partnera

\footnotetext{
${ }^{30}$ Usp. Erickson, Reconceptualizing family work..., 893; Mustafa PAMUK, Emine DURMUŞ, Investigation of burnout in marriage, Journal of Human Sciences, 12 (2015) 1, 162-177, 174.

${ }^{31}$ Usp. Josip OBRADOVIĆ i dr., Bračni odnosi i stabilnost braka, Revija za sociologiju, 23 (1992) 3-4, 147-169, 147.

${ }^{32}$ Usp. Blažeka Kokorić, Povezanost..., 124, 146, 206.

${ }^{33}$ Usp. Frank D. FINCHAM, Marital conflict: Correlates, structure, and context, Current directions in psychological science, 12 (2003) 1, 23-27, 23.

${ }^{34}$ Usp. Masoumeh SHOKROLLAHZADEH, Monireh FOROUZESH, Hossein HOSSEINI, The effect of cognitive behavioral couple therapy on marital conflicts and marital burnout, Family Pathology, Counseling and Enrichment Journal, 3 (2017) 1, 115-131, 115.
} 
da će ostati zajedno do kraja života. ${ }^{35}$ Ovakve spoznaje govore u prilog tome da je izuzetno važno pravovremeno zaustaviti spiralu negativnih iskustava povezanih s doživljajem nerješivosti partnerskih sukoba, ako se želi prevenirati emocionalno sagorijevanje i raspad partnerskog odnosa. U situacijama kada partneri doživljavaju u svom odnosu eskalaciju učestalih, neriješenih sukoba te kada nisu zadovoljni strategijama ni efikasnošću njihova rješavanja, važno je da pravovremeno potraže pomoć stručnjaka. Ranija istraživanja pokazuju da terapijske i druge stručne intervencije mogu biti efikasne u pogledu rješavanja partnerskih sukoba, smanjivanja emocionalnog sagorijevanja i unapređivanja kvalitete partnerskog odnosa. ${ }^{36}$ Primjerice, nalazi studije provedene na kontrolnoj i eksperimentalnoj skupini od 32 para, pokazali su da kognitivno-bihevioralna terapija s promjenom negativnih uvjerenja parova i sprečavanjem bračnih sukoba može značajno smanjiti bračno sagorijevanje. ${ }^{37}$ Za konstruktivno razrješavanje partnerskih sukoba može biti korisno i uključivanje parova u obiteljsku medijaciju u kojoj se partneri usmjeravaju na rješavanje problema pregovaranjem i olakšavanjem komunikacije, a stručnjak medijator im pomaže pri identificiranju potreba, briga i strahova, ali i osmišljavanju izvedivih i prihvatljivih rješenja sukoba radi postizanja zajedničkog sporazuma. ${ }^{38} \mathrm{Na}$ taj način partneri mogu steći iskustvo veće efikasnosti u rješavanju partnerskih sukoba, što je izuzetno bitno za obnovu povjerenja te za daljnji razvoj i budućnost partnerskog odnosa.

\section{Zaključak}

Nalazi ovog istraživanja potvrđuju da karakteristike partnerskih sukoba imaju važnu ulogu u doživljaju emocionalnog sagorijevanja i budućnost partnerskog odnosa. Rezultati pokazuju da je veća izraženost neslaganja u partnerskom odnosu i manja efikasnost rješavanja partnerskih sukoba povezana s većim emocionalnim sagorijevanjem i odustajanjem od odnosa. Jednako tako potvrđeno je da veća efikasnost rješavanja sukoba pozitivno korelira sa spremnošću na aktivno ulaganje u odnos, a negativno s odustajanjem od odnosa. Nalazi upućuju na zaključak da je sukobe u partnerskom odnosu nužno promatrati i razumijevati u povezanosti s drugim odrednicama partnerskog odnosa.

${ }^{35}$ Claire M. KAMP DUSH, Miles G. TAYLOR, Trajectories of marital conflict across the life course. Predictors and interactions with marital happiness trajectories, Journal of Family Issues, 33 (2012) 3, 341-368, 341.

${ }^{36}$ Usp. Asgari, Goodarzi, The Effectiveness of Emotional Schema Therapy..., 55; Hatice DEVECI ŞIRIN, Mehmet Engin DENIZ, The effect of the Family Training Program on Married Women's Couple-Burnout Levels, Educational Sciences. Theory E Practice, 16 (2016) 5, 1563-1585, 1563.

${ }^{37}$ Usp. Shokrollahzadeh, Forouzesh, Hosseini, The effect of cognitive..., 115

${ }^{38}$ Usp. Branka SLADOVIĆ FRANZ, Obilježja obiteljske medijacije, Ljetopis socijalnog rada, 12 (2005) 2, 301-320. 
Istraživački rezultati ukazuju na važnost prepoznavanja »znakova opasnosti« u partnerskom odnosu te ističu važnu ulogu pravovremenog uključivanja parova $\mathrm{s}$ teškoćama u partnerskom odnosu u različite oblike profesionalne podrške za konstruktivno razrješavanje sukoba, sprečavanje emocionalnog sagorijevanja i daljnju eroziju odnosa. U navedenom kontekstu, usluge obiteljske medijacije, savjetovanja i bračne terapije imaju izuzetno značenje te je stoga važno ulagati daljnje napore u unapređenje dostupnosti i kvalitete navedenih usluga na području cijele Hrvatske. Dakle, rezultati ovog istraživanja ukazuju na važnost daljnjeg istraživanja i produbljivanja znanstvenih spoznaja o fenomenu emocionalnog sagorijevanja koji je u domaćim istraživanjima do sada bio proučavan samo u kontekstu sagorijevanja na radnom mjestu. S obzirom da je ova tema do sada ostala neopravdano istraživački zanemarena u kontekstu proučavanja odrednica bračne nestabilnosti, u budućim istraživanjima na širem uzorku važno je nastaviti primjenjivati hrvatsku verziju Upitnika bračnog sagorijevanja za koju se pokazalo u ovom istraživanju da ima zadovoljavajuću faktorsku strukturu i visoku razinu pouzdanosti. Također, s obzirom na to da u domaćoj znanstvenoj publikaciji izraženo nedostaju istraživanja usmjerena na analizu teškoća u partnerskim odnosima i načina njihova rješavanja iz perspektive osoba koje su uključene u proces savjetovanja, dobiveni rezultati u ovom istraživanju imaju praktičnu vrijednost u kontekstu provođenja edukacija studenata i stručnjaka u ovom području, ali i poticanja daljnjih istraživanja. 


\section{Slavica Blažeka Kokorić" - Gordana Stolfa*** \\ The Correlation between the Characteristics of Conflicts in Partner Relation- ships, the Experience of Emotional Burnout and Assessment of the Future of the Partner Relationship}

\section{Summary}

The paper presents the results of research aimed at determining whether there is a correlation between the characteristics of conflicts in partner relationships and experience of emotional burnout and assessment of the future of the partner relationship. Data was collected by means of a survey questionnaire administered to the sample of 149 persons who were involved in psychosocial counselling due to difficulties in their partner relationships. The survey questionnaire consisted of the following measurement instruments: The Questionnaire on the Socio-Demographic Characteristics of Research Participants, the Questionnaire on Marital Burnout, the Questionnaire on the Future of the Partner Relationship and the Conflicts and Problem-solving Scales. Descriptive statistics, chi-square test, t-test and Pearson's correlation coefficient were used in data analysis. The research results showed that persons involved in counselling due to difficulties in their partner relationship often experience emotional burnout in the partner relationship, namely on a weekly basis, and that they express an ambivalent attitude towards the future of the relationship. In doing so, they are equally ready for further active investment in the relationship, as well as for withdrawing from the relationship. There are not significant differences between men and women in assessment of emotional burnout and the future of the partner relationship, nor in assessment of the frequency of minor and major conflicts in the partner relationship. The largest percentage of research participants, namely $29.73 \%$, experience minor conflicts in their partner relationship almost every day, while $26.35 \%$ experience them on a weekly basis and $27.03 \%$ on a monthly basis. Regarding major conflicts in the partner relationship, $6.80 \%$ of participants experience them almost every day, while $21.77 \%$ of participants experience them on a weekly basis and $20.41 \%$ on a monthly basis. A quarter of participants (23.13\%) report experiencing major conflicts once per year or even less frequently. Participants in this research assess that their conflicts more often result in the conflicts becoming more profound than in conflict resolution. The results of the correlation analysis showed that a higher degree of disagreement in a partner relationship correlates with a lower willingness to actively invest in the relationship, with more frequent emotional burnout and withdrawal from the relationship. Furthermore, it has

\footnotetext{
* Slavica Blažeka Kokorić, PhD, Full Prof., University of Zagreb, Faculty of Law, Social Work Study Centre; Address: Nazorova 51, HR-10000 Zagreb, Croatia; E-mail: sblazeka@pravo.hr.

**Gordana Stolfa, univ. spec. mediat., Nursing home »Mali Kartec«; Address: Lina Bolmarčića 1, HR-51500 Krk, Croatia, E-mail: gordana.stolfa@mail.inet.hr.
} 
been found that more frequent efficient conflict resolution and conflict resolution capability correlates with a greater willingness to actively invest in a relationship and with a lesser degree of emotional burnout and withdrawal from the relationship. More frequent experiences with negative conflict outcomes in the form of the conflict becoming more profound are associated with a more frequent experience of emotional burnout and more frequent withdrawal from the partner relationship. In conclusion, the paper emphasises the importance of further development and greater availability of professional services aimed at providing support to partners in terms of constructive resolution of their conflicts in order to prevent the occurrence of emotional burnout and instability of partner relationships in a timely manner.

Key words: conflicts in partner relationships, conflict resolution efficiency, emotional burnout, withdrawal from the relationship.

(na eng. prev. Emanuel Ježić-Hammer) 